\title{
Microparticles in snow from the South Greenland ice sheet
}

Steffensen, Jørgen Peder

Published in:

Tellus B

DOI:

10.1111/j.1600-0889.1985.tb00076.x

Publication date:

1985

Document version

Publisher's PDF, also known as Version of record

Citation for published version (APA):

Steffensen, J. P. (1985). Microparticles in snow from the South Greenland ice sheet. Tellus B, 37 B(4-5), 286295. https://doi.org/10.1111/j.1600-0889.1985.tb00076.x 


\section{Tellus B: Chemical and Physical Meteorology}

\section{Microparticles in snow from the South Greenland ice sheet}

\section{J. P. Steffensen}

To cite this article: J. P. Steffensen (1985) Microparticles in snow from the South Greenland ice sheet, Tellus B: Chemical and Physical Meteorology, 37:4-5, 286-295, DOI: $10.3402 /$ tellusb.v37i4-5.15031

To link to this article: https://doi.org/10.3402/tellusb.v37i4-5.15031

$$
\begin{aligned}
& \text { (c) } 1985 \text { The Author(s). Published by Taylor \& } \\
& \text { Francis. }
\end{aligned}
$$

曲 Published online: 18 Jan 2017.

Submit your article to this journal

Џ Article views: 36

Q View related articles $₫$

4 Citing articles: 6 View citing articles 준 


\title{
Microparticles in snow from the South Greenland ice sheet
}

\author{
By J. P. STEFFENSEN, Department of Glaciology, Geophysical Institute, University of Copenhagen, \\ Haraldsgade 6, DK-2200 Copenhagen N, Denmark
}

(Manuscript received June 24; in final form August 20, 1985)

\begin{abstract}
A detailed analysis of the concentration and the size distribution of insoluble microparticles (dust) in snow from the South Greenland ice sheet covering the years 1980-1983 has been carried out. An approximative description of the temporal variations of the size distributions has been obtained using Junge distributions to describe the general features of the measured size distributions in the size interval $0.55-2.5 \mu \mathrm{m}$. Variations of the 3 measured parameters, the bulk dust concentration, $N_{0.9}$, the slope of the Junge distribution, $\beta$, and the $\delta^{18} \mathrm{O}$ value of the snow are compared and discussed. The slope, $\beta$, varies seasonally, i.e., low values in winter and high in summer, and $\beta$ appears to be closer related to the $\delta^{18} \mathrm{O}$ values of the snow than the bulk dust concentration. In conclusion, analysis of the dust-size distribution may help to improve stratigraphic ice-core dating. The $\delta^{18} \mathrm{O}$ values of the snow are found to vary in parallel with the temperature at coastal stations in South Greenland. This opens the possibility to date snow strata of the order of a month, provided that diffusion has not yet obliterated the subannual variations of $\delta^{18} \mathrm{O}$.
\end{abstract}

\section{Introduction}

During the last few decades, studies of the content of insoluble microparticles (dust) in snow and ice have been carried out on ice cores and pit samples from glaciers and polar ice sheets. It has been shown that the dust concentration in glacier snow and ice shows seasonal variations with high concentrations in summer precipitation and low concentrations in winter precipitation (Hamilton and Langway, 1968; Koerner, 1977; Thompson, 1977; Hammer, 1977a). Furthermore, dust concentration peaks are often found in spring/early summer precipitation (Koerner, 1977; Hammer, 1977a). These seasonal variations have been applied for ice-dating purposes in parallel with other similar methods based on the isotopic, chemical and physical properties of the ice (Hammer et al., 1978; Langway et al., 1977).

Most of the dust found in the Greenland and Antarctic ice sheets has been carried from distant continental sources as a tropospheric aerosol, and deposited on the surface by wash-out by precipitation or dry deposition (Junge, 1977). The dust concentration in the ice depends on processes in the source area, the atmosphere and on the glacier surface; hence it contains information about past environmental conditions and the atmospheric circulation. As to the tropospheric aerosol, the size distribution of the microparticles between 0.1 and $10 \mu \mathrm{m}$ radius can be described approximately by the Junge distribution (Junge, 1963; Jaenicke and Davies, 1976):

$$
\begin{aligned}
& \frac{\mathrm{d} N(r)}{\mathrm{d} \log r}=\alpha \cdot r^{-\beta} \\
& \text { or } \\
& \log \frac{\mathrm{d} N(r)}{\mathrm{d} \log r}=\log \alpha-\beta(\log r),
\end{aligned}
$$

where $N(r)$ is the number of particles with radii greater than $r$ per $\mathrm{ml}$ of air (STP). In this work, the Junge distribution is used to characterize the measured size distributions of the insoluble microparticles in the size interval $0.55-2.5 \mu \mathrm{m} . N(r)$ is the number of particles per $\mathrm{ml}$ of water. Natural logarithms are used. The units of $r$ are $\mu \mathrm{m}$. The basic mechanisms that determine the concentration 
of microparticles in precipitation, are today fairly well understood (Junge, 1977), but little is known about the influence of processes on the ice sheet surface, e.g., snowdrift, melting and refreezing.

Below, a detailed dust-size distribution profile from a pit study on the South Greenland ice sheet is presented along with a bulk-dust concentration profile and a $\delta^{18} \mathrm{O}$ profile, $\delta^{18} \mathrm{O}$ being the relative deviation of the ${ }^{18} \mathrm{O}$ concentration in a sample from that of Standard Mean Ocean Water (SMOW). The discussion of the results includes coastal meteorological observations and stratigraphic features in the snow.

\section{Fieldwork}

In 1983, a pit study was carried out in the DYE-3 area on the South Greenland ice sheet $\left(65^{\circ} \mathrm{N}, 44^{\circ} \mathrm{W}\right.$, elev. $\left.2500 \mathrm{~m}\right) 12 \mathrm{~km}$ upstream from the GISP 81 deep bore hole (Dansgaard et al., 1982). Two continuous series of 143 ice samples each were collected on June 23, 1983 from a vertical pit wall, starting from the surface and to $3.35 \mathrm{~m}$ depth (resolution $2.3 \mathrm{~cm}$ ): one series for dust and one for $\delta^{18} \mathrm{O}$ analysis. After cleaning the surface of the pit wall with a stainless steel knife, the features of visible stratigraphy were recorded. The samples were then taken by pushing $25 \mathrm{ml}$ clean plastic beakers (Accuvette ${ }^{7}$ ) into the pit wall and breaking off the samples by twisting the beakers. In order to improve dating of the bottom part of the pit profile, data from a $5 \mathrm{~m}$ core, drilled $10 \mathrm{~m}$ from the pit, are included in the study. The samples were kept frozen until analysis.

\section{Experimental}

The dust concentration and size distribution were measured in a class 100 clean room by a Coulter-Counter model $\mathrm{Z}_{\mathrm{B}}$ connected to a Nuclear Data 66 multichannel analyzer The samples were melted at room temperature, and $12 \mathrm{ml}$ of each was diluted with $12 \mathrm{ml}$ clean $2 \% \mathrm{NaCl}$ electrolyte for Coulter analysis. The Coulter Counter and the multichannel analyzer were calibrated to $5 \%$ accuracy in particle size determination using a Coulter Counter calibration standard of spherical, "monosized" polystyrene particles with a mean radius of $0.575 \mu \mathrm{m}$. Calibration was also checked by standards with mean radii of $0.5055 \mu \mathrm{m}$ and $2.85 \mu \mathrm{m}$.
The Coulter Counter measures particle volumes, even for somewhat irregular particles. The size parameter, $r$, is thus the equivalent radius under the assumption that the particles are spherical. In this investigation, all particles between 0.4 and $5.07 \mu \mathrm{m}$ were counted by the Coulter Counter. The experimental set-up also provided an estimate of the number of particles larger than $5.07 \mu \mathrm{m}$ for each sample. The number of particles between 5.07 and about $15 \mu \mathrm{m}$ was of the order of $1-10$ particles per $\mathrm{ml}$, and the number of particles larger than about $15 \mu \mathrm{m}$ was lower than 1 per $\mathrm{ml}$. In this work, particles larger than $5.07 \mu \mathrm{m}$ are omitted, although their contribution to the total particle volume in a few extreme cases might be significant. By applying the light scattering method, as described by Hammer (1977b), an estimate of the total volume of the dust particles larger than $0.05 \mu \mathrm{m}$ was obtained (Hammer, 1977c). The light scattering results showed essential agreement with the volume determined by the Coulter Counter, indicating that the particle volume between 0.05 and $0.5 \mu \mathrm{m}$ was less than $20 \%$ of the total volume. This is in agreement with results from scanning-electron microscopy on insoluble particles from Camp Century, North Greenland (Kumai, 1977), and from comparing light scattering and Coulter Counter results with the total aluminium content obtained by atomic absorption measurements on samples from Milcent and Crête (Hammer, 1977c; Langway et al., 1977; Hammer et al., 1978). The bulk of the dust mass therefore consists of particles larger than $0.5 \mu \mathrm{m}$, and $N_{0.5}$, i.e. the total number of particles larger than $0.5 \mu \mathrm{m}$ per $\mathrm{ml}$ is used as a bulk dust concentration parameter. The light scattering method also provided an easy check for possible contamination during preparation and Coulter measurement, as the risk of contamination in the light scattering method is significantly lower. The agreement between the Coulter and light scattering measurements also indicated insignificant contamination.

Each sample (sample volume: $0.5 \mathrm{ml}$ ) was counted in each radius interval $0.04-0.08 ; 0.56-$ $1.27 ; 0.88-2.01 ; 1.40-3.19 ; 2.23-5.07 \mu \mathrm{m}$. Each interval was counted with a size resolution of 235 channels in the multi-channel analyzer. The width of each channel varied with $r$, but it never exceeded $2 \%$ of the $r$ value. Several channels in the large particle range had often very low or no counts; therefore in order to improve counting statistics, a 
mean value of the counts and radius of these channels was formed, before the complete size distribution was printed out in a double logarithmic diagram (exemplified in Fig. 1), and fitted by a least squares cubic spline. The slope of the distribution, $\beta$ in eq. (1), was determined by a linear regression analysis between $0.55 \mu \mathrm{m}$ and $2.5 \mu \mathrm{m}$. The standard deviation of $\beta$ is estimated to be less than $3 \%$. $N_{0.3}$ was obtained by integration of the spline fit. The standard deviation of $N_{0,5}$ was lower than $3 \%$.

\section{Results}

4 size distributions are shown in Fig. 1. Three of them (samples 27, 133 and 42; Fig. 1a, lb and 1c) are representative, and resemble the Junge distribution, although they have different slopes and bulk concentrations. Sample 66 (Fig. 1d) is the only extreme case, where the size distribution has a significant curvature. Sample 66 was taken in a snow layer at $1.82 \mathrm{~m}$ depth, where a narrow dust concentration peak is found. This layer will be discussed in subsection 5.2. The Junge distribution (eq. (1)) is used here as an approximative description of the measured size distributions over the range $0.55-2.5 \mu \mathrm{m}$. Although this description does not characterize the measured size distributions in detail, it makes it possible to represent the size distributions by the slope, $\beta$, and the concentration, $N_{0,5}$. A plot of the $\beta$ profile along the pit wall is shown in Fig. 2b. The mean size distribution of all the samples is shown in Fig. 3.

Fig. 2a shows the $\delta^{18} \mathrm{O}$ profiles along the pit wall (full curve), and along the $5 \mathrm{~m}$ core (dashed curve) measured in $5 \mathrm{~cm}$ increments. As $15 \mathrm{~cm}$ of the core was lost during drilling, mainly around $1.80 \mathrm{~m}$ depth, the depth scale of the latter profile has been slightly adjusted on the basis of stratigraphic features (shown on the outer right). The $\delta^{18} \mathrm{O}$ profiles show that the pit samples span precipitation from late winter-spring 1980 to spring-early summer 1983.

Fig. $2 \mathrm{c}$ shows the bulk dust concentration, $N_{0.5}$, profile along the pit wall. The mean value is 9400 particles $/ g$ ice. The weekly mean temperature and precipitation curves shown in Fig. 4a and $4 \mathrm{~b}$ are derived from synoptical observation data from the coastal stations: Holsteinsborg, Godthaab, Frederikshaab (in South-West Greenland), and Angmagssalik (in South-East Greenland). As the individual temperature and precipitation curves from these stations follow essentially the same pattern (this may not hold in general), the mean curves in Fig. 4 are considered representative for South Greenland.

\section{Discussion}

\subsection{Effects of melt layers}

DYE- 3 is located in an area of the Greenland ice sheet, where moderate summer melting occurs at the surface. In this study $\sim 2 \mathrm{~cm}$ refrozen melt layers are encountered at depths $1.18 \mathrm{~m}, 2.04 \mathrm{~m}$, $2.18 \mathrm{~m}$ and $2.26 \mathrm{~m}$. Furthermore, the depth intervals $2.08-2.18 \mathrm{~m}, 2.82-2.88 \mathrm{~m}$ and $2.96-2.98 \mathrm{~m}$ show minor but definite indications of melt. In Fig. 2, the melt layer at $1.18 \mathrm{~m}$ is recognizable in all of the three profiles. However, in general, the $\delta^{18} \mathrm{O}$ profile seems to be only slightly, or not at all affected by the melt layers. The $N_{0.5}$ profile shows a concentration peak in the melt layer at $1.18 \mathrm{~m}$, relatively low concentrations in the melt layers at 2.18 and $2.26 \mathrm{~m}$, and the concentration appears unaffected in the melt layer at $2.02 \mathrm{~m}$. In principle, both high and low dust concentrations could be encountered within a melt layer. Such concentration changes within a melt layer have also been observed for strong acids (H. B. Clausen, personal communication). The $\beta$ profile appears to be most affected, see the low values at $1.18 \mathrm{~m}$, at $2.04 \mathrm{~m}$ and at $2.11 \mathrm{~m}$. Low $\beta$ values indicate relatively many large particles in the melt layers relative to the normal size distribution. This change in size distribution may be due to size fractionation of the dust particles during melting and refreezing, but the process is complicated, including water seeping through porous firn, adhesive forces on ice grain boundaries, gravitational settling, coagulation, etc.

\subsection{Dust concentration and size distribution}

The dust concentration profile in Fig. $2 \mathrm{c}$ shows annual variation with higher concentration levels in summer deposits, and with peaks located in spring/early summer deposits. The peaks are often sharp, indicating 3-4 times higher than normal dust concentration in short periods of precipitation. A possible explanation for these spring peaks is that the precipitation has been formed under arctic haze conditions in the atmosphere (of course only the insoluble fraction of arctic haze can contribute to the dust profile in Fig. 2c). Arctic haze has been 
a) Somple 27, depth $2.73 \mathrm{~m}, \mathrm{~N}_{0.5}=5919$.

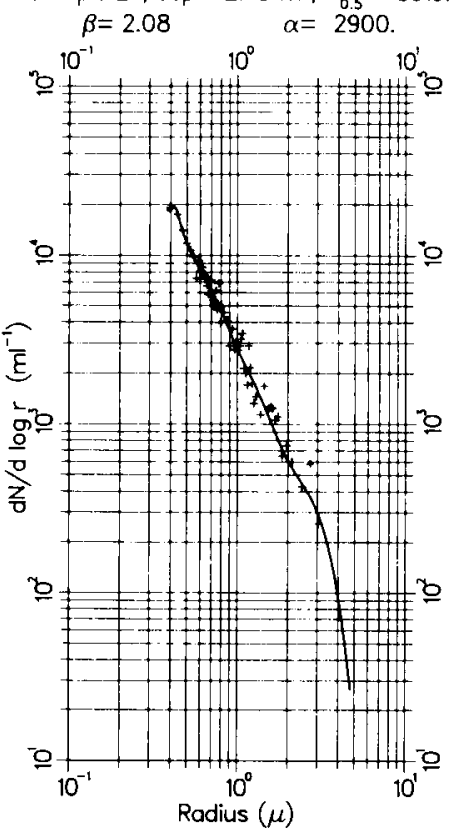

c) Sample 42, depth $2.38 \mathrm{~m}, \mathrm{~N}_{0.5}=11060$.

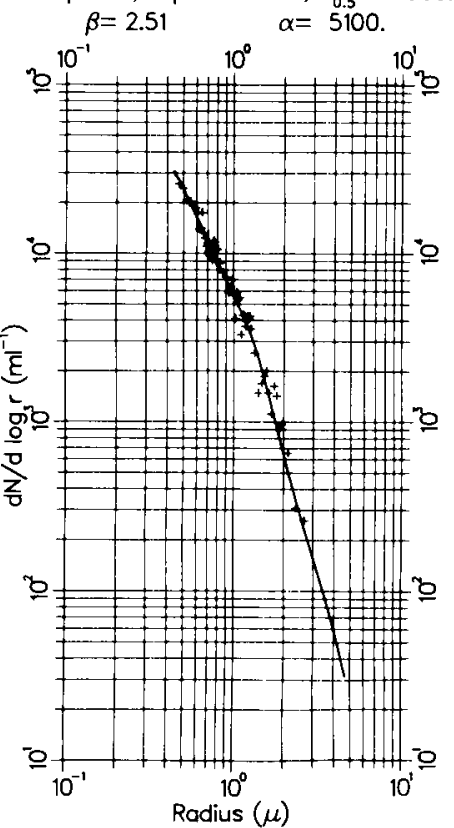

b) Sample 133, depth $0.26 \mathrm{~m}, \mathrm{~N}_{0.5}=12041$.

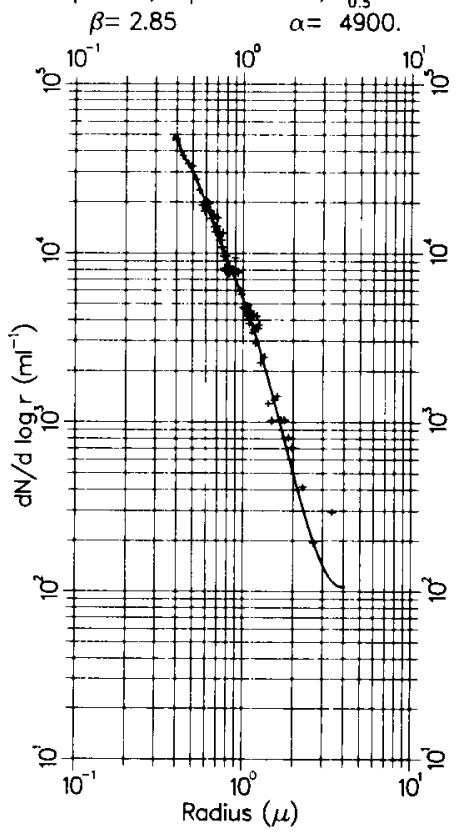

d) Sample 66, depth $1.82 \mathrm{~m}, \mathrm{~N}_{0.5}=19569$.

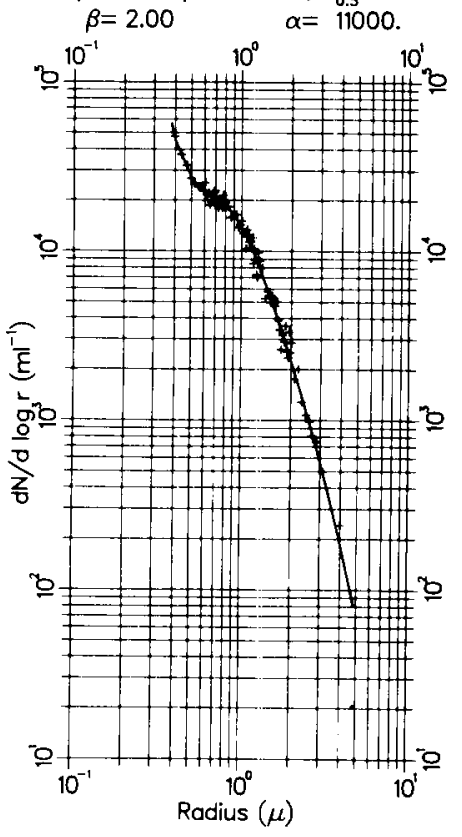

Fig. 1. Four individual size distributions. The sample number, sample depth, and dust concentration are written in the headings together with the results of the linear regression analysis. The slope, $\beta$, and the interception with $r=1.0 \mu \mathrm{m}$, $\alpha$. The solid line shows a least squares spline fit of the measured size distribution. Each point represents a mean of the counts in 10 channels. 


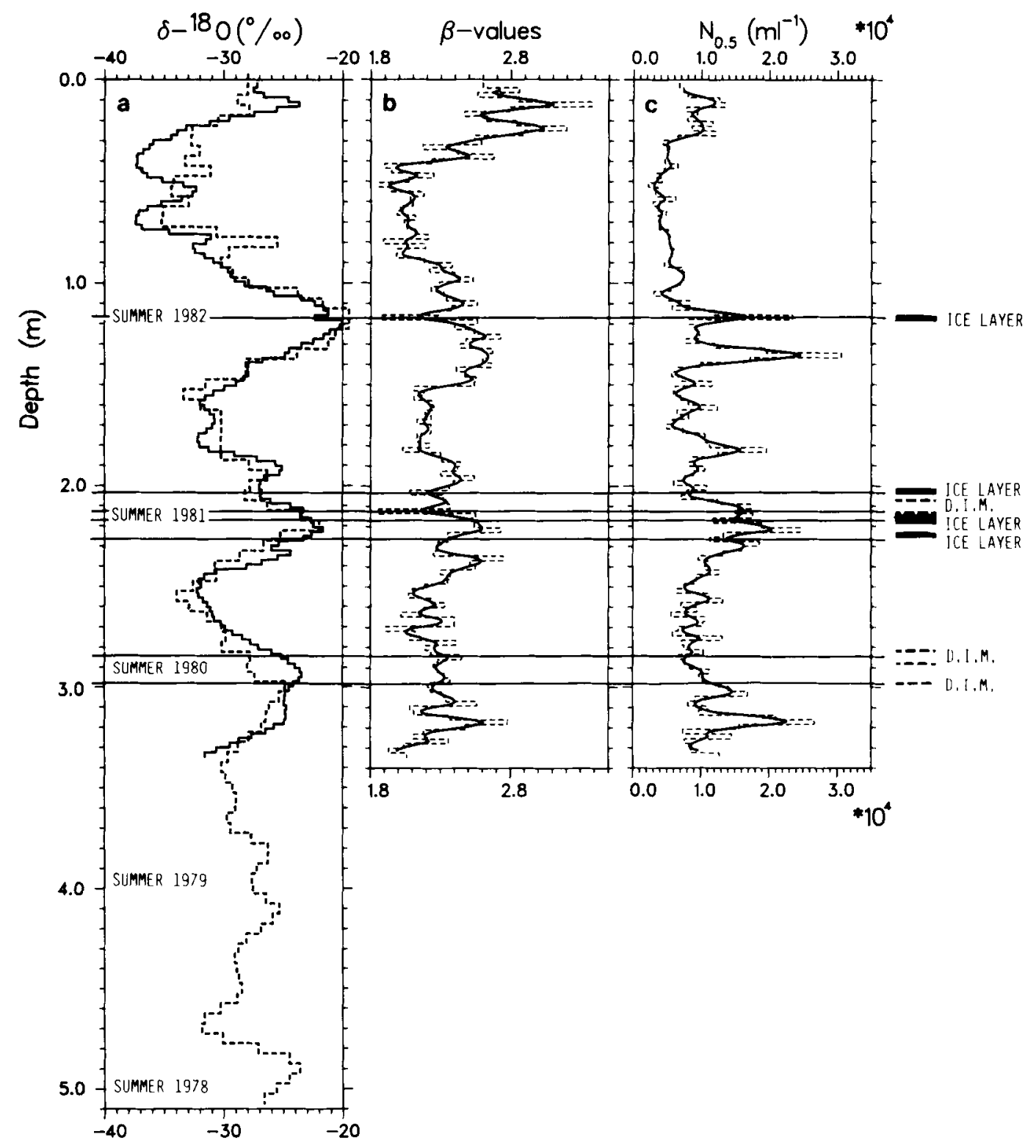

Fig. 2. Vertical profiles of the three parameters: $\delta^{18} \mathrm{O}, \beta$ value, and $N_{0.5}$. Visible stratigraphic features are shown as horizontal lines and commented on the right. D.I.M. means Definite Indication of Melt. In Fig. 2a, the solid line is the $\delta^{18} \mathrm{O}$ profile obtained from the pit, and the dashed line is the profile from the $5 \mathrm{~m}$ core drilled $10 \mathrm{~m}$ away. Fig. $2 \mathrm{~b}$ shows the $\beta$ (slope of the Junge distribution) profile and Fig. $2 \mathrm{c}$ shows the $N_{0.5}$ (bulk dust concentration) profile. The dashed lines in Fig. $2 b$ and Fig. $2 c$ show the measured profiles, and the solid lines show the smoothed profiles.

reported to show maximum optical depth in April-May over Fairbanks, Alaska, and it has been observed in the atmosphere over the Greenland ice sheet (Shaw, 1982). Another possible explanation is that a blocking anticyclonic system occurs very regularly each spring over Greenland causing 
Mean distribution, $\mathrm{N}_{0.5}=9441$.

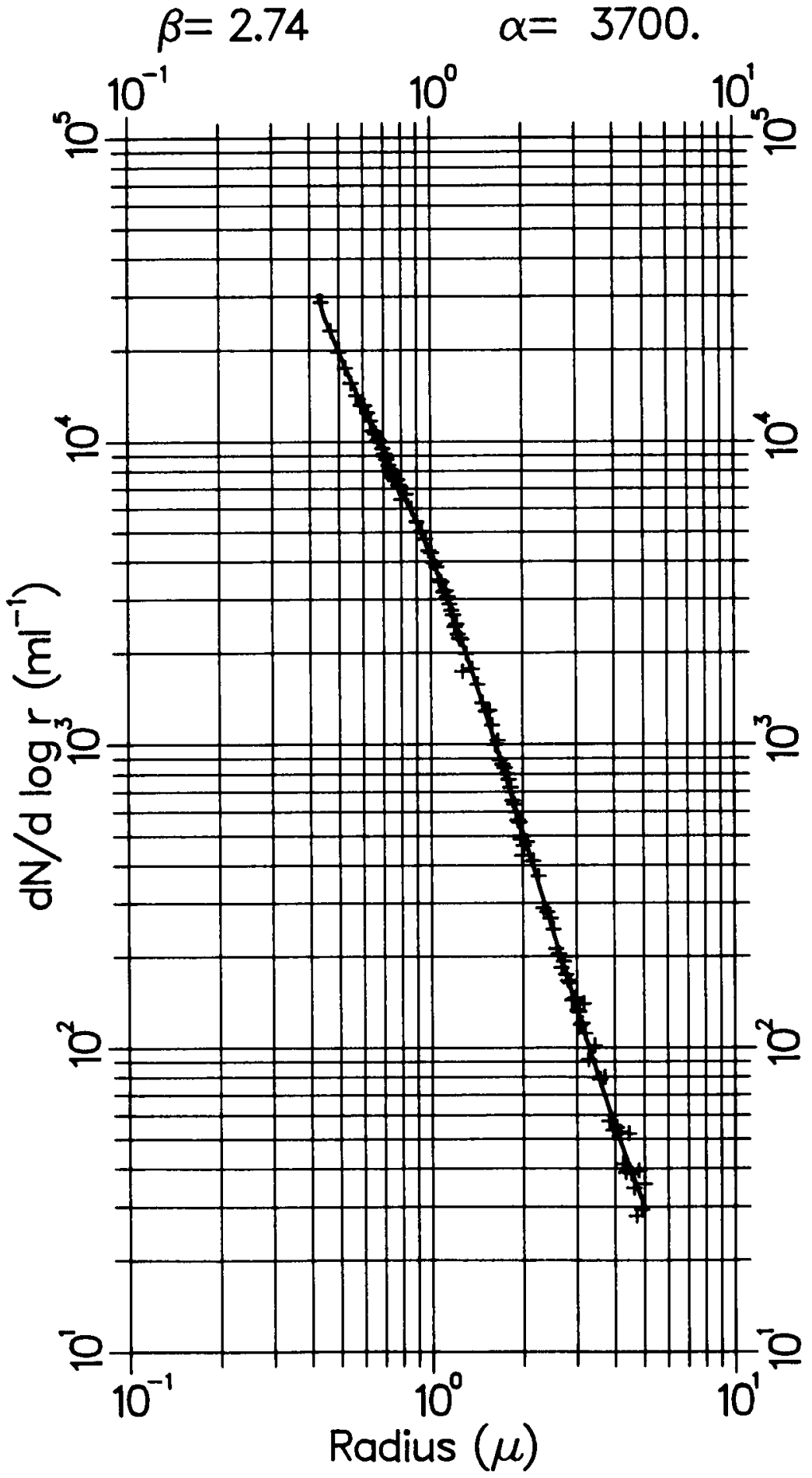



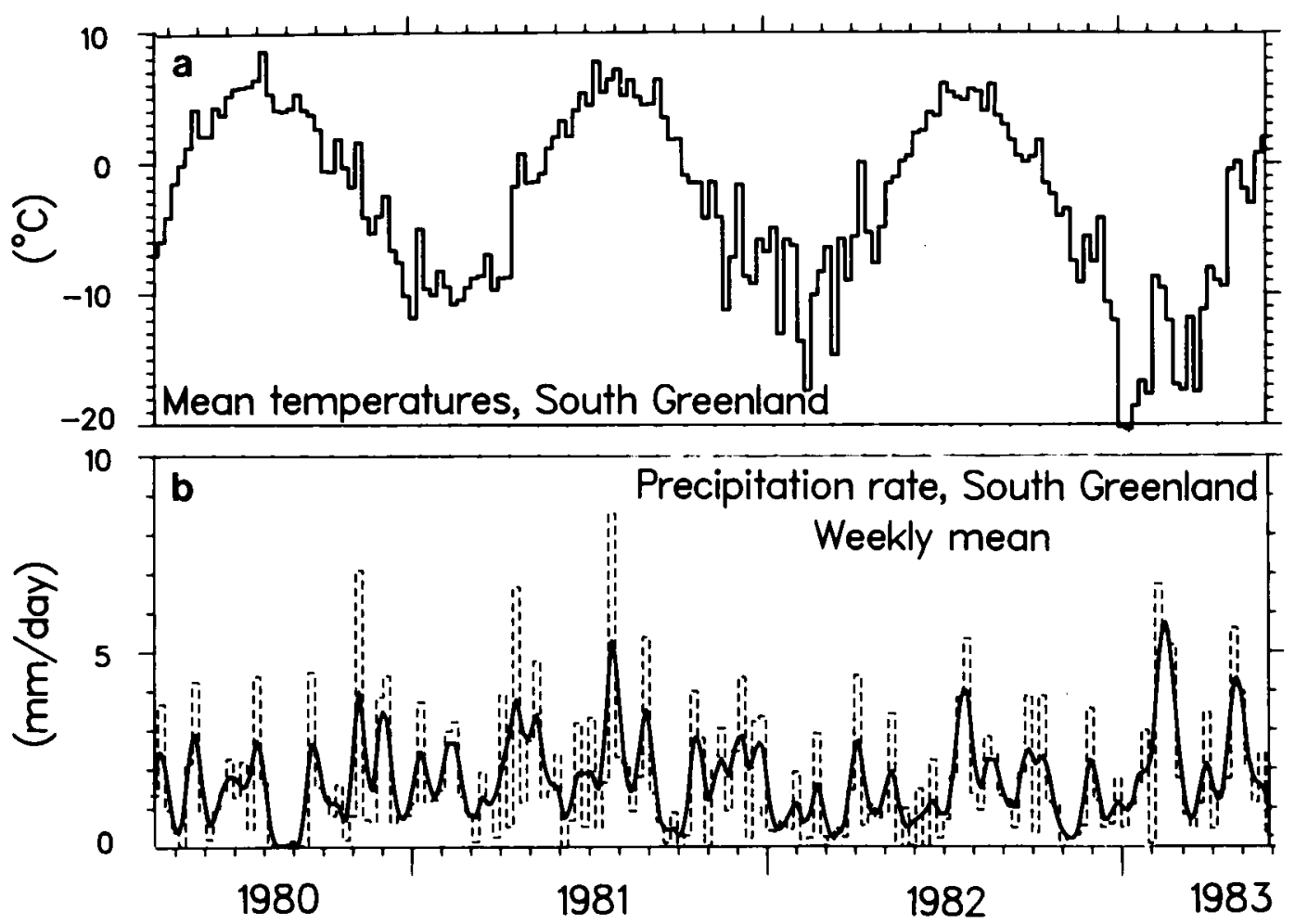

Fig. 4. Meteorological observations in South Greenland. Temperatures (Fig. 4a) and precipitation rates (Fig. 4b) are weekly means from four stations: Holsteinborg, Godthaab, Frederikshaab and Angmagssalik. The dashed line shows the calculated rates, and the solid line shows the smoothed variation of the precipitation rate.

strong and persistent winds across the ice sheet from the source areas in North America (Hammer et al., 1978).

The spring peak phenomenon combined with the dust concentration peaks induced by melting/ refreezing may have implications for the dating method based on counting of spring/summer dust peaks downwards from the surface, which is important, particularly as regards old ice, in which the annual cycles of $\delta^{18} \mathrm{O}$ are obliterated by diffusion (Johnsen, 1977). However, counting annual layers solely by seasonal variations of dust concentration involves a risk of misinterpretation due to the noisy character of the dust concentration profile. Spring/summer layers may show two or more peaks, and dust peaks may occur outside this season, see the early winter peak at $1.82 \mathrm{~m}$ in Fig. 2c, which might have been counted as a summer layer if the $\delta^{18} \mathrm{O}$ profile were not available. No relationship exists between the details of the dust concentration profile (Fig. $2 \mathrm{c}$ ) and the $\delta^{18} \mathrm{O}$ profile (Fig. 2a), but the dust concentration level is higher in summer layers than in winter layers.

In contrast, comparison of the $\beta$ and $\delta^{18} \mathrm{O}$ profiles (Fig. 2b and 2a) shows that almost every change in the $\delta^{18} \mathrm{O}$ profile is reflected by a change in the $\beta$ profile. However, the $\delta^{18} \mathrm{O}$ profile has already been somewhat smoothed by diffusion, and details therefore tend to disappear in course of time, i.e., with increasing depth. This apparently simultaneous change of $\beta$ and $\delta^{18} \mathrm{O}$ suggests that a change in $\beta$ coincides with the presence of a new aerosol and therefore a new precipitating "air mass". A closer analysis requires sampling with higher resolution and application of the "back diffusion" method (Johnsen, 1977) to restore high frequency variations of the $\delta^{18} \mathrm{O}$ profile.

The dust concentration peaks are generally not associated with significant variations in $\beta$ (except in 
melt layers), and the connection between $\beta$ and $N_{0.5}$ is not clear. High dust concentrations occur in low $\beta$ layers (e.g. at $1.85 \mathrm{~m}, 2.30 \mathrm{~m}$ and $2.45 \mathrm{~m}$ (Fig. 2)), as well as in high $\beta$ layers (e.g. at $0.10 \mathrm{~m}, 1.50 \mathrm{~m}$ and $3.15 \mathrm{~m}$ ).

Some of the size distributions have a moreor-less developed curvature, but none of the curvatures (except sample 66) seem so strongly developed that it invalidates a straight line approximation. The deviations from the Junge distribution, e.g., kinks and different curvatures of the distribution curves, have been analyzed, but no systematic relation to $\beta, N_{0.5}, \delta^{18} \mathrm{O}$, or season could be observed. The observed size distributions resemble the size distributions of the total tropospheric aerosols in remote areas.

DYE -3 is a remote area in so far as all possible aerosol sources, except for the radar station itself, are more than $100 \mathrm{~km}$ away. The observed $\beta$ values at an elevation of $2500 \mathrm{~m}$ agree with measurements on the mid-tropospheric total aerosol (Junge et al., 1969; Junge, 1963) and with $\beta$ values found in ice from Camp Century (Kumai, 1977) and Crête (Hammer, personal communication), Greenland, and from Dome C, Antarctica (Petit et al., 1981).

Generally, winter precipitation has lower $\beta$ values than summer precipitation. Since the winter snowcover in North America and East Asia makes the source areas of the aerosol more remote, the winter aerosol is expected to mainly represent the high tropospheric background aerosol. The low winter $\beta$ 's may also be a consequence of a less efficient removal of the large particles from the troposphere before the "air masses" reach DYE-3, e.g., because the precipitation rates in winter are lower, or because of stronger winds in winter (Petit et al., 1981). However, it is important, to keep in mind that this study only deals with the insoluble fraction of the tropospheric aerosol omitting such important condensation nuclei as sea salt particles and particles containing $\mathrm{H}_{2} \mathrm{SO}_{4}$.

\subsection{The temperature to $\delta^{18} \mathrm{O}$ relationship}

Most of the characteristic temperature variations in South Greenland (Fig. 4a) also appear in the $\delta^{18} \mathrm{O}$ profile (Fig. 2a). Even temperature changes of short duration, i.e., 2 weeks or less, are sometimes represented by a corresponding shift in the $\delta^{18} \mathrm{O}$ value, at least in the upper snow layers where many of the high frequency variations of the $\delta^{18} \mathrm{O}$ values are not yet obliterated by diffusion. Unlike the temperature curve, the $\delta^{18} \mathrm{O}$ profile is not a true time series because it only represents the periods of precipitation, and because the snow layers are modified by snowdrift on the surface. Hence, one should not expect a perfect correlation between the temperature curve and the $\delta^{18} \mathrm{O}$ profile.

The temperature observations (Fig. 4a) have been plotted as a function of the corresponding precipitation rates (Fig. 4b), instead of time, as shown in Fig. 5 (thin curve). Based on the density measurements from the nearby $5 \mathrm{~m}$ core, the depth scale of the $\delta^{18} \mathrm{O}$ profile (Fig. 2a) along the pit wall has been transformed into a depth scale corresponding to equal density, see the heavy curve in Fig. 5. The 2 gaps are inserted on the basis of characteristic features of the curves. They correspond to $10-20 \mathrm{~cm}$ of "missing" snow, and to $10-20 \mathrm{~cm}$ "excess" snow in the pit profile, respectively, which may be ascribed to sastrugi formation. In the DYE-3 area, surface snow is often observed to pile up in sastrugies of $10-20 \mathrm{~cm}$ thickness and with a lateral extent of few meters. This gives the snow layers an uneven lateral distribution, and snow layers identified in one vertical profile may therefore appear thicker, thinner or even be missing in another profile nearby.

The concurrence of the curves in Fig. 5 shows that a $\delta^{18} \mathrm{O}$ profile reflects the temperatures in South Greenland, under favourable conditions even in details corresponding to time intervals of few weeks, provided (i) there has been precipitation to carry the information to the ice sheet surface, (ii) stratigraphy has not been disturbed by sastrugi formation, and (iii) the details in the $\delta^{18} \mathrm{O}$ profile have not yet been obliterated by diffusion and recrystallisation via the vapour phase in the snow pack. As long as these conditions are fulfilled, reconciliation of $\delta^{18} \mathrm{O}$ profiles with coast station temperature records may therefore serve as an indirect means for the dating of snow layers with an accuracy of the order of a month. The temporal relationship between $\delta^{18} \mathrm{O}$ and coastal average temperatures is $0.7 \%$ per ${ }^{\circ} \mathrm{C}$, in essential agreement with the $0.62 \%$ per ${ }^{\circ} \mathrm{C}$ found as the geographical relationship between annual mean surface temperatures and $\delta^{18} \mathrm{O}$ values at several stations on the Greenland ice sheet (Dansgaard et al., 1973). 


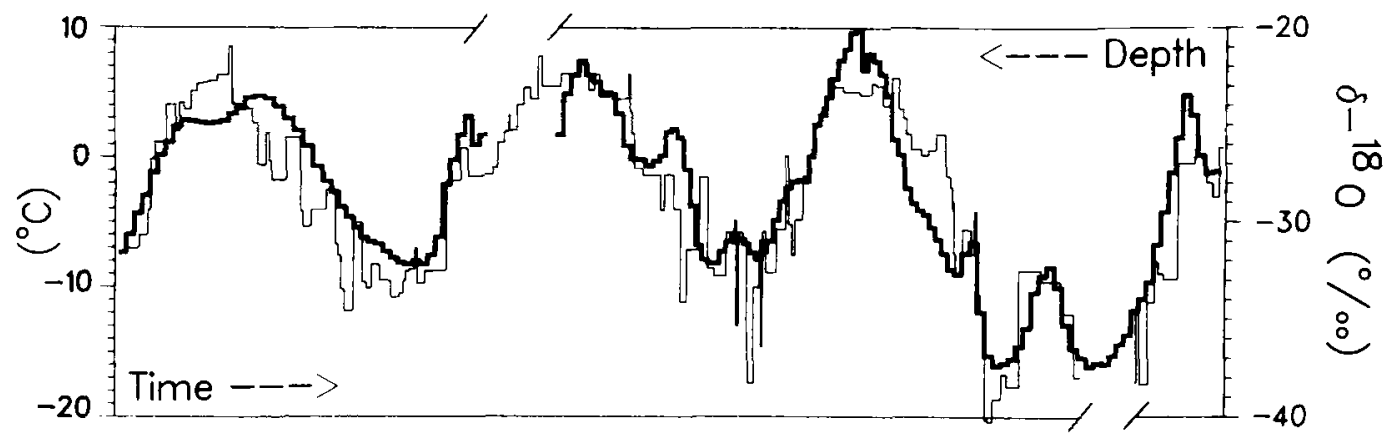

Fig. 5. Comparison of the South Greenland coastal temperature observations, and the measured $\delta^{18} \mathrm{O}$ values. Thin curve: temperatures from Fig. 4 a plotted as a function of precipitation rates from Fig. $4 \mathrm{~b}$; heavy curve: $\delta^{18} \mathrm{O}$ profile from Fig. 2a adjusted on the basis of density measurements. The gaps are inserted on the basis of characteristic features of the curves.

\section{Summary and conclusion}

Analysis of snow from the South Greenland ice sheet, accumulated during $1980-1983$ has yielded a size distribution profile of the insoluble microparticles in the snow. In this profile, the seasonal variations of the size distribution can be monitored by characterizing each measured size distribution by a Junge distribution with slope $\beta$ in the size interval $0.55-2.5 \mu \mathrm{m} . \beta$ shows seasonal variations with higher values in summer than in winter. It is generally more closely related to the $\delta^{18} \mathrm{O}$ values of the snow than the concentration, $N_{0.5} . \beta$ is found to be within the range of the $\beta$ values reported from the high and midtropospheric total aerosols. In melt layers, $\beta$ is lowered due to changes in the size distribution during the melting/refreezing process. Since $\beta$ appears to have more clear seasonal variations than the dust concentration, measurement of $\beta$ might help improve the accuracy of identifying annual layers based on the dust content in ice cores, where seasonal variations of $\delta^{18} \mathrm{O}$ are missing due to diffusion or low accumulation.

$\delta^{18} \mathrm{O}$ values of the snow vary in parallel with the temperature at coastal stations in South Greenland.
Under favourable conditions, reconciliation of $\delta^{18} \mathrm{O}$ profiles with coastal temperature records therefore opens the possibility of dating the snow strata with an accuracy of the order of a month, as far back in time as it takes the diffusion to obliterate the sub-annual details in the $\delta^{18} \mathrm{O}$ profile.

No significant difference could be observed between the temporal and geographical temperature effects on $\delta^{18} \mathrm{O}$.

\section{Acknowledgements}

The author wishes to thank M. Møhl-Madsen and N. Lund, the Danish Space Research Institute for kindly providing the multichannel analyzer used in this study; P. Aakjær, the Danish Meterological Institute for providing meteorological data from Greenland, and C. U. Hammer for valuable discussions. This work has been supported by the Danish Commission for Scientific Investigations in Greenland, The Danish Natural Science Research Council and the European Economic Communities (contract CLI-067 DK (G)).

\section{REFERENCES}

Dansgaard, W., Johnsen, S. J., Clausen, H. B. and Gundestrup, N. 1973. Stable isotope glaciology. Meddelelser om Grenland 197, no. 2.

Dansgaard, W., Clausen, H. B., Gundestrup, N., Hammer, C. U., Johnsen. S. J., Kristinsdottir, P. M. and Reeh, N. 1982. A new Greenland deep ice core. Science 218, 1273-1277.
Hamilton, W. L. and Langway, C. C. Jr. 1968. A correlation of microparticle concentrations with oxygen isotope ratios in 700 year old ice. Earth planet. sci. lett. 3, 363-366.

Hammer, C. U. 1977a. Dating of Greenland ice cores by microparticle concentration analysis. Proc. Symp. on isotopes and impurities in snow and ice, 
Grenoble, IAHS-AISH Publication no. 118, 297-301.

Hammer, C. U. 1977b. Dust studies on Greenland ice cores. Proc. Symp. on isotopes and impurities in snow and ice, Grenoble, IAHS AISH Publication no. 118, 365-370.

Hammer, C. U. 1977c. Past volcanism revealed by Greenland ice sheet impurities. Nature 270, 482-486.

Hammer, C. U., Clausen. H. B., Dansgaard, W., Gundestrup, N., Johnsen, S. J. and Reeh, N. 1978. Dating of Greenland ice cores by flow models, isotopes, volcanic debris and continental dust. $J$. Glaciol. 20. 3-26.

Jaenicke, R. and Davies, C. N. 1976. The mathematical expression of the size distribution of atmospheric aerosols. J. Aerosol Sci. 7. 255-259.

Johnsen, S. J. 1977. Stable isotope homogenization of polar firn and ice. Proc. Symp. on isotopes and impurities in snow and ice. Grenoble. IAHS-AISH Publication no. 118, 210-219.

Junge, C. E. 1963. Air chemistry and radioactivity. Academic Press, New York.

Junge. C. E., Robinson. E. and Ludwig, F. L. 1969. A study of aerosols in Pacific air masses. J. Appl. Meteorol. 8, 340-347.

Junge. C. E. 1977. Processes responsible for the trace content in precipitation. Proc. Symp. on isotopes and impurities in snow and ice. Grenoble. IAHS-AISH Publication no. 118,63-77.
Koerner, R. M. 1977. Distribution of microparticles in a $299 \mathrm{~m}$ ice core through Devon Island ice cap, Northwest Territories, Canada. Proc. Symp. on isotopes and impurities in snow and ice, Grenoble, IAHS-AISH Publication no. 118, 371-376.

Kumai, M. 1977. Electron microscope analysis of aerosols in snow and deep ice cores from Greenland. Proc. Symp. on isotopes and impurities in snow and ice. Grenoble, IAHS-AISH Publication no. 118 , $341-350$.

Langway, C. C. Jr, Klouda, G. A., Herron, M. M. and Cragin, J. H. 1977. Seasonal variations of chemical constituents in annual layers of Greenland deep ice deposits. Proc. Symp. on isotopes and impurities in snow and ice. Grenoble, IAHS-AISH Publication no. $118,302-306$.

Petit, J.-R., Briat, M. and Royer, A. 1981. Ice age aerosol content from East Antarctic ice core samples and past wind strength. Nature 293, 391-394.

Shaw, G. E. 1982. Atmospheric turbidity in the polar regions. J. Appl. Meteorol. 21, 1080-1088.

Thompson, L. G. 1977. Variations in microparticle concentration, size distribution and elemental composition found in Camp Century, Greenland and Byrd station, Antarctica deep ice cores. Proc. Symp. on isotopes and impurities in snow and ice, Grenoble, IAHS-AISH Publication no. 118, 351-362. 